\title{
Олександр КОМАРНІЦЬКИЙ
}

доктор історичних наук, доцент,

професор кафедри історії України,

Кам'янець-Подільський національний університет ім. І.Огієнка

(Кам'янець-Подільський, Україна), kob-1974@ukr.net

ORCID: https://orcid.org/oooo-0oo3-302I-6550

\section{Ірина НЕДОШИТКО}

кандидатка історичних наук,

доцентка кафедри інформаційної та соціокультурної діяльності,

Західноукраїнський національний університет

(Тернопіль, Україна), i.nedoshytko@ukr.net

ORCID: https://orcid.org/oooo-oooi-9233-7169

\section{Більшовизація студентів педагогічних закладів національних меншин в УСРР/УРСР 1920-1930-х рр.: мета, засоби, завдання}

DOI: https://doi.org/10.15407/uhj202I.02.093

УДК: 94(477):373-057.875:323.15《192/193»

\begin{abstract}
Анотація. Мета дослідження полягає у з'ясуванні мети, засобів і завдань більшовизації студентства закладів педагогічної освіти національних меншин у 1920-1930-х рр., висвітленні громадсько-політичної і просвітницької діяльності студентської молоді, цілеспрямованої та контрольованої партійними й комсомольськими осередками в педтехнікумах, інститутах, у цілому партійно-державницькими структурами, а також проявів в її середовищі опозиційних настроїв. Методологія. Використано комплекс загальнонаукових (аналіз, синтез, порівняння, діалектичний) та спеціально-наукових (історико-генетичний, історико-порівняльний, історико-типологічний, проблемно-хронологічний) методів історичного пізнання. Наукова новизна. Проаналізовано громадсько-політичне життя студентства педагогічних навчальних закладів крізь призму його більшовизації. Висновки. Для більшовизації студентської молоді, нав'язування їй радянсько-сталінської ідеології й моделі суспільства партійні та комсомольські осередки у закладах педагогічної освіти національних меншин практикували організацію політичних гуртків, гуртків «поточної політики», політичних і комсомольських шкіл, «політбоїв», «соціалістичного змагання», поширення атеїстичних ідей, відзначення державних свят та ін. На практиці такі заходи, як і самі партійні та комсомольські комітети, належним авторитетом серед студентів здебільшого не користувалися. Натомість у молодіжному середовищі популярними були різні диспути та дискусії на політичні теми з вільним обміном думками, що, на думку влади, несло загрозу виробленню «марксистського світогляду». Політико-ідеологічним настановам більшовицької партії й комсомолу було підпорядковано громадсько-політичну та просвітницьку діяльність студентів. Зокрема ї залучали до роботи у складі профспілок, громадських організацій, гуртків, до участі в різних загальнодержавних кампаніях, шефській роботі на селі, на підприємствах у містах, у робітничих клубах, підрозділах Червоної армії та ін. Загалом студенти педагогічних технікумів й інститутів були менш активними у суспільній роботі, особливо у селах, ніж їхні ровесники з суто українських вишів. Частина студентів не сприйняла більшовицької моделі суспільства, проявляла опозиційні настрої, що неминуче призводило до репресій в їхньому середовищі.
\end{abstract}

Ключові слова: студентство, педагогічний інститут, технікум, більшовицька ідеологія, комітет, соцзмагання. 
3 утвердженням більшовицької влади навчання та виховання молоді були одним із пріоритетних напрямів внутрішньої політики радянської держави. Систему освіти використовували як засіб цілеспрямованого впливу на свідомість населення. Тому особлива увага приділялася виробленню ідеологічного світогляду майбутніх учителів, які мали формувати політичну свідомість підростаючого покоління за комуністичними лекалами. Головною метою відповідних навчальних закладів було визначено виховання студентів у «марксистсько-ленінському дусі», формування «свідомого» й «політично грамотного» громадянина. Окремі аспекти цієї проблеми, насамперед теоретичні, містяться у працях Г.Шевчука І.Кліцакова 5 , К.Двірної ${ }^{6}$ та ін. Громадсько-політичне життя студентства педагогічних вишів радянської України вказаного періоду було предметом монографічного дослідження О.Комарніцького ${ }^{7}$. Поза увагою фахівців залишилося питання більшовизації студентів-педагогів національних меншин. Нижче ця проблема в такому формулюванні розглядатиметься вперше.

Визначальним фактором в організації ідеологічної роботи серед студентства закладів педагогічної освіти була робота осередків КП(б)У і ЛКСМУ, які чисельно зростали. Так, парторганізація Київського російського педтехнікуму зросла 3 3 осіб у 1932/1933 навч. р. до І2 в наступному ${ }^{8}$ у Преславському болгарському у грудні 1929 р. числилося 5 комуністів, 2 з яких були студентами ${ }^{9}$. Комсомольські осередки були більш чисельними. Зокрема в тому ж Преславському педагогічному технікумі в 1929/1930 навч. р. 72 студенти були комсомольцями ${ }^{\text {10}} ;$ у Житомирському єврейському наприкінці 1925/1926 навч. р. - 35 $5^{\text {II }}$, а в березні 1927 р. - уже $54^{12}$; у Вінницькому єврей-

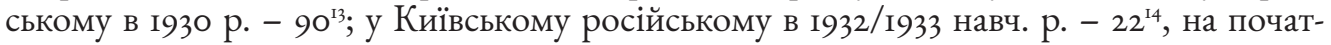
ку 1933/1934 навч. р. - 44, а вже наприкінці того року - $73^{15} ;$ у Київському польському в I931/1932 навч. р. $-60^{16}$.

Природно, що більш активну роботу в молодіжному середовищі провадили чисельні комсомольські осередки, які організаційно та ідейно підпорядковувалися більшовицькій партії. Разом вони були складовою політичного, ідеологічно-пропагандистського й репресивно-карального механізмів.

Поточну роботу в комсомольських осередках педзакладів вели бюро. У Житомирському єврейському педтехнікумі в березні 1927 р. воно складалося з 5 членів і

\footnotetext{
Шевчук Г.М. Культурне будівництво на Україні у 1921-1925 рр. - К., 1963. - 436 с.

2 Паніотов I.I. Комуністична партія України в боротьбі за розвиток народної освіти (1931-1941 рр.). - Х., 1973. $188 \mathrm{c}$.

3 Рябченко О. Студенти радянської України 1920-1930-х рр.: практики повсякденності та конфлікти ідентифікації. Х., 2012. - C.95-217.

4 Лаврут О.О. Діяльність студентів у гуртках // Наукові праці. - Т.115. - Вип.102: Історія. - Миколаїв, 2009. - С.27-35.

s Клічаков I.О. Педагогічні кадри України (1917-1937 pр.). - Донецьк, 1997. - 310 с.

6 Двірна К. Створення і ліквідація Польського педагогічного інституту в м. Києві в 30-х рр. XX ст. (архівна розвідка) // Волинські історичні записки. - Т.6. - Житомир, 2011. - С.152-153.

Комарніщъкий О.Б. Студенти-педагоги у модернізації вищої освіти радянської України у 1920-1930-х рр. Кам'янець-Подільський, 2017. - С.322-564.

8 Державний архів (далі - Держархів) м. Києва. - Ф.Р.359. - Оп.1. - Спр.66. - Арк.22; Спр.67. - Арк.83.

9 Центральний державний архів вищих органів влади та управління України (далі - ЦДАВО України). - Ф.166. -

Оп.10. - Спр.825. - Арк.152.

10 Там само.

${ }_{11}$ Держархів Житомирської обл. - Ф.Р.266. - Оп.1. - Спр.142. - Арк.11 зв.

12 Там само. - Ф.П.211. - Оп.1. - Спр.10. - Арк.40.

13 Держархів Вінницької обл. - Ф.П.29. - Оп.1. - Спр.620. - Арк.166.

14 Держархів м. Києва. - Ф.Р.359. - Оп.1. - Спр.67. - Арк.83.

15 Там само. - Спр.66. - Арк.23.

${ }_{16}$ ЦДАВО України. - Ф.166. - Оп.10. - Спр.1490. - Арк.34.
} 
2 кандидатів, які працювали в піонерській та агітаційно-пропагандистській комісіях ${ }^{17}$. Усіх їх зобов’язували брати участь у загальних зборах, де розглядалися різноманітні питання (наприклад, із І вересня 1935 по г лютого 1936 рр. такі: «Рішення XI пленуму ЦК ЛКСМ і завдання нашої комсомольської організації», «Про виховання жіночої молоді», «Про академуспішність комсомольців та студентів», «Про передплату газет комсомольцями», «Про італо-абіссінську війну», «Про культурно-побутові умови студентів», «Про XVIII-річчя Жовтня», «Про стаханівський рух» тощо) ${ }^{18}$.

Комсомольців, які своїми діями дискредитували організацію, виключали 3 ЛКСМУ. Так, у лютому 1935 р. за крадіжки в гуртожитку було виключено комсомольця Проскурівського польського педагогічного технікуму Малішевського. Крім того, у протоколі засідання комітету комсомолу цього закладу від I5 лютого І93І р. зазначалося, що він проявив «явно шкідницьку ідеологію»: ухилявся від виконання завдань комітету, зривав політнавчання, задавав одному з пропагандистів питання «контрреволюційного змісту ${ }^{19}$.

Серед заходів, якими опікувалися компартійні та комсомольські осередки з метою виховання у студентів «марксистсько-ленінського світогляду», особливе значення надавалося організації політичних («марксистських», «ленінських») гуртків. Вони мали «доповнити академічну працю соціальних дисциплін у напрямкові пристосування академічних здобутків до масової політосвітньої роботи на селі і серед робітничих та селянських мас» ${ }^{20}$. Такі гуртки працювали у Вінницькому (у г931/1932 навч. p. тут було гз політгуртків ${ }^{21}$ ), Житомирському ${ }^{22}$, Одеському ${ }^{23}$, Харківському єврейських (у 1925/1926 навч. р. - 4 політгуртки) $)^{24}$, Дніпропетровському ${ }^{25}$ та Київському російських педтехнікумах ${ }^{26}$. Робота деяких із них була кволою, приміром, у Житомирському єврейському педагогічному технікумі - через слабку підготовку керівника гуртка ${ }^{27}$. Натомість у Проскурівському польському в першому семестрі 1934/1935 навч. р. незадовільною вважалася робота гуртка марксизму-ленінізму, який практично не функціонував ${ }^{28}$.

Упродовж другої половини 1920 - початку 1930-х рр. поряд із політгуртками функціонували гуртки поточної політики (як у Вінницькому єврейському педтехнікумі ${ }^{29}$.

У 1930-х рр. в навчальних педзакладах організовувалися політичні школи. Так, у Київському російському педагогічному технікумі в 1933/1934 навч. p. їх було $7^{30}$. Політшколи функціонували також у Житомирському єврейському закладі ${ }^{31}$. У них студенти вивчали праці «класиків марксизму-ленінізму», історію ВКП(б) і профспілкового руху, у цілому займалися «політграмотою» ${ }^{2}$. Заняття проводилися переважно лекційним методом. Слухачі вчилися не надто охоче, тож навчальні показники були

${ }_{17}$ Держархів Житомирської обл. - Ф.П.211. - Оп.1. - Спр.10. - Арк.40.

18 Там само. - Ф.П.215. - Оп.1. - Спр.6. - Арк.10.

19 Держархів Хмельницької обл. - Ф.Р.2597. - Оп.1. - Спр.18. - Арк.99 зв.

${ }^{20}$ ЦДАВО України. - Ф.166. - Оп.6. - Спр.415. - Арк.40.

${ }_{21}$ Там само. - Оп.10. - Спр.1495. - Арк.68.

22 Держархів Житомирської обл. - Ф.П.211. - Оп.1. - Спр.10. - Арк.40.

${ }^{23}$ ЦДАВО України. - Ф.166. - Оп.5. - Спр.264. - Арк.71 зв.

24 Там само. - Арк.29.

${ }_{25}$ Держархів Дніпропетровської обл. - Ф.П.7. - Оп.1. - Спр.1489. - Арк.2.

${ }^{26}$ ЦДАВО України. - Ф.166. - Оп.10. - Спр.1490. - Арк.51.

27 Держархів Житомирської обл. - Ф.П.211. - Оп.1. - Спр.10. - Арк.40.

28 Держархів Вінницької обл. - Ф.П.457. - Оп.1. - Спр.444. - Арк.154.

29 Там само. - Ф.П.29. - Оп.1. - Спр.620. - Арк.165.

30 Держархів м. Києва. - Ф.Р.359. - Оп.1. - Спр.66. - Арк.23 зв.

31 Центральний державний архів громадських об'єднань України (далі - ЦДАГО України). - Ф.7. - Оп.1. - Спр.1079. Арк.255.

32 Морозан О.О. Позанавчальна діяльність майбутніх педагогічних працівників на Миколаївщині у 20-30-ті рр. XX ст. // Науковий вісник Миколаївського державного університету ім. В.О.Сухомлинського: Іст. науки. - Вип.21. Миколаїв, 2008 [Електронний ресурс]: http://www.nbuv.gov.ua/old_jrn/Soc_Gum/Nvmdu/Ist/2008_21/Morozan.pdf 
не найкращими. Наприклад, у політшколах Київського російського педтехнікуму в 1933/1934 навч. р. на «добре» навчалося 27,2\%, «задовільно» - 44,2\%, а «незадовільно» - аж 28,6\% студентів ${ }^{33}$.

Поряд із політичними працювали ще й комсомольські школи, в яких молодь «підвищувала» свій «ідейний рівень». Так, у Житомирському єврейському педтехнікумі в 1932 р. розпочали роботу 4 таких навчальних осередки ${ }^{34}$. У 1935 р. тут діяли 3 школи, які охопили 108 осіб, у тому числі 7І комсомольця та 37 безпартійних. Того року було проведено І5 політзанять 35 .

Активізації ідеологічної роботи серед студентства слугувала організація марксистсько-ленінських і комсомольських семінарів (працювали, наприклад, у Вінницькому єврейському ${ }^{36}$ й Київському російському педтехнікумах $\left.{ }^{37}\right)$, агітаційно-пропагандистських комісій (колективів), основу яких становили студенти (як у випадку з Житомирським єврейським закладом $)^{38}$.

Функціонували гуртки з вивчення окремих ідеологічних проблем. У Дніпропетровському російському педагогічному технікумі в 1928/1929 навч. р. працював суспільствознавчий гурток ${ }^{39}$; у Житомирському єврейському в 1937 р. - школа з вивчення Конституцій СРСР та УРСР4․ У Польському педінституті в 1933/1934 навч. р. діяли політекономічні гуртки ${ }^{41}$.

Між окремими групами студентів організовувалися змагання («політбої», «політвікторини»), під час яких перевірялося, наскільки вони засвоїли матеріали партійних з'іздів, пленумів ЦК ${ }^{42}$. Так, у Київському російському педтехнікумі в першому семестрі 1932/1933 навч. р. провели «політбій» за рішеннями пленумів ЦК ВКП(б). Найкращі показники мали І3 студентів, котрі відповіли на I4 із I5 питань, за що їх преміювали ${ }^{43}$. «Політбої» проводилися також у Вінницькому єврейському педагогічному технікумі ${ }^{44}$. Відбувалися вони й між навчальними закладами, як, наприклад, у г93і р. у Житомирі між сільськогосподарським інститутом та єврейським педтехнікумом ${ }^{45}$. Київський російський у першому семестрі 1932/1933 навч. р. посів 2-ге місце на загальноміській «політвікторині» ${ }^{46}$.

Індоктринацію молоді влада намагалася здійснювати засобами, популярними серед студентів. Зокрема проводилися різні диспути та дискусії на політичні теми. 28 грудня 1922 р. ЦК КП(б)У направив циркулярного листа бюро партосередків навчальних закладів на предмет важливості організації диспутів із питань марксизму. Доповідачами були безпартійні професори, які інколи вносили «поправки» до вчення К.Маркса. Серед слухачів фіксувалися ті студенти, котрі великої ваги надавали таким словам, що ставило, на думку керівництва партосередку, під загрозу вироблення «правильного марксистського світогляду» ${ }^{47}$. Із Дніпропетровського російського педтехнікуму повідомлялося, що в 1928/1929 навч. р. партійний і комсомольський

\footnotetext{
33 Держархів м. Києва. - Ф.Р.359. - Оп.1. - Спр.66. - Арк.23 зв.

${ }_{34}$ ЦДАВО України. - Ф.166. - Оп.9. - Спр.1796. - Арк.8.

35 Держархів Житомирської обл. - Ф.П.215. - Оп.1. - Спр.12. - Арк.5, 7, 9 зв.

${ }_{36}$ ЦДАВО України. - Ф.166. - Оп.10. - Спр.1495. - Арк.68.

37 Держархів м. Києва. - Ф.Р.359. - Оп.1. - Спр.27. - Арк.7.

38 Держархів Житомирської обл. - Ф.П.211. - Оп.1. - Спр.10. - Арк.40.

39 Держархів Дніпропетровської обл. - Ф.П.7. - Оп.1. - Спр.1489. - Арк.2.

40 Держархів Житомирської обл. - Ф.П.215. - Оп.1. - Спр.12. - Арк.10.

41 Держархів м. Києва. - Ф.Р.920. - Оп.11. - Спр.18. - Арк.6, 75 зв.

${ }_{42}$ Бабко Ю.В. Партійне будівництво на Україні у 1933-1937 рр. - Л., 1971.- С.84.

43 Держархів м. Києва. - Ф.Р.359. - Оп.1. - Спр.69. - Арк.4.

${ }_{44}$ ЦДАВО України. - Ф.166. - Оп.10. - Спр.1495. - Арк.68.

${ }_{45}$ Держархів Житомирської обл. - Ф.П.211. - Оп.1. - Спр.36. - Арк.24; Спр.40. - Арк.42.

46 Держархів м. Києва. - Ф.Р.359. - Оп.1. - Спр.69. - Арк.4.

47 ЦДАГО України. - Ф.1. - Оп.20. - Спр.1448. - Арк.229.
} 
осередки авторитетом у студентства не користувалися. Провину покладали на «реакційну» частину викладачів, які розповідали молоді про «таємні студентські організації», «шпигунські функції комсомольців» ${ }^{8}$.

У педтехнікумах для виховання «комуністичного ставлення до праці» організовували «соціалістичне змагання». За розрахунками керівництва, це мало активізувати навчальну та ідеологічну роботу. Уважалося, що «соцзмагання» було добровільним виявом ініціативи викладачів і студентів, але насправді його організовували за наказами згори. Напередодні змагання кожен заклад брав на себе зобов’язання. Так, у вересні 1933 р. серед педтехнікумів УСРР найкращим виявився Хортицький німецький ${ }^{49}$.

Суперництво відбувалося, як правило, між окремими педтехнікумами. Наприклад, у 193І/1932 навч. р. Житомирський єврейський змагався зі своїми колегами з Вінниці та Одеси ${ }^{50}$. У $1933 / 1934$ навч. р. Проскурівський польський вступив у

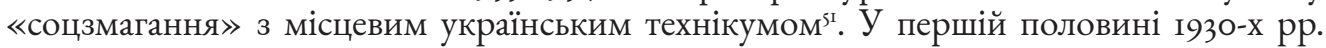
Київський російський щорічно змагався з польським ${ }^{52}$, а Вінницький український з єврейським педагогічним технікумом ${ }^{53}$.

Подекуди угоди на «соціалістичне змагання» укладали навчальні заклади різного рівня. Так, Вінницький єврейський педтехнікум у 1929/1930 навч. р. змагався з єврейським відділом молодшого концентру Одеського інституту народної освіти ${ }^{54}$. Крім того, угоди на «соцзмагання» укладалися між закладами різного відомчого підпорядкування. Наприклад, у січні 1930 р. профком Вінницького єврейського педтехнікуму викликав на змагання сільськогосподарський технікум по лінії ліквідації неписьменності. Перший із них брав на себе зобов'язання навчити читати й писати 400 осіб і закликав підтримати їхню ініціативу колег з агротехнікумуэ5. Житомирський єврейський педтехнікум у 1932/1933 навч. р. уклав угоду на змагання з садово-городнім технікумом, запросивши арбітром редакцію газети «Радянська Волинь» ${ }^{56}$.

Підсумки змагань між навчальними закладами грунтувалися на показниках колективного суперництва між факультетами й курсами, що відбувалося безпосередньо в технікумах. Переможців нагороджували перехідним червоним прапором у різних номінаціях: найкращі курс, група, кімната в гуртожитку⿰7 (як це було, наприклад, у Хортицькому німецькому педтехнікумі $)^{58}$. Водночас запроваджувалися відзнаки і для аутсайдерів «соцзмагань». Наприклад, у Вінницькому єврейському педагогічному технікумі в 1931/І932 навч. р. один із курсів отримав «рогожку»59.

Важливим ідеологічним прийомом «соцзмагання» було «ударництво», коли частина студентів, що «включалися» в індивідуальне змагання, оголошували себе «ударниками», тобто мали бути першими в усьомуб. Наприклад, у Дніпропетровському російському педтехнікумі зі г2з студентів, які брали участь у змаганні, ударниками себе

48 Держархів Дніпропетровської обл. - Ф.П.7. - Оп.1. - Спр.1489. - Арк.126.

49 ЦДАГО України. - Ф.7. - Оп.1. - Спр.906. - Арк.44.

50 ЦДАВО України. - Ф.166. - Оп.9. - Спр.1796. - Арк.9.

1 Держархів Хмельницької обл. - Ф.Р.2597. - Оп.1. - Спр.6. - Арк.2 зв.

52 ЦДАВО України. - Ф.166. - Оп.10. - Спр.1490. - Арк.34, 50; Держархів м. Києва. - Ф.Р.359. - Оп.1. - Спр.11. Арк.7; Спр.66.- Арк.23; Спр.67. - Арк.95; Спр.135. - Арк.17.

${ }_{3}$ Держархів Вінницької обл. - Ф.П.249. - Оп.1. - Спр.15. - Арк.26; Ф.Р.1179. - Оп.1. - Спр.13. - Арк.45 зв. - 46, 70 зв.

54 Там само. - Ф.П.29. - Оп.1. - Спр.620. - Арк.164.

55 Там само. - Ф.Р.3510. - Оп.2. - Спр.7. - Арк.159.

56 ЦДАВО України. - Ф.166. - Оп.9. - Спр.1796. - Арк.9.

57 ЦДАВО України. - Ф.166. - Оп.10. - Спр.1495. - Арк.70; Держархів Вінницької обл. - Ф.П.457. - Оп.1. Спр.442. - Арк.10; Спр.444. - Арк.159 зв.; Держархів Хмельницької обл. - Ф.Р.302. - Оп.1. - Спр.2097. - Арк.27;

Держархів м. Києва. - Ф.Р.359. - Оп.1. - Спр.67. - Арк.95.

${ }_{58}$ ЦДАВО України. - Ф.166. - Оп.11. - Спр.326. - Арк.39.

59 Там само. - Оп.10. - Спр.1495. - Арк.70.

60 Паніотов I.I. Комуністична партія України в боротьбі за розвиток народної освіти (1931-1941рр.). - С.63. 
оголосили го3 $(83,7 \%)^{\text {6. }}$. Щодо інших закладів, то маємо неповні дані. Так, у Польському педінституті у 2-му семестрі 1933/1934 навч. р. було $394^{62}$, у Житомирському єврейському педтехнікумі в 1935/1936 навч. р. - I80 ${ }^{63}$, у Київському польському в 1934/1935 навч. p. - 40 64, у Проскурівському польському в 1933/1934 навч. p. - 30 ударників ${ }^{65}$. У Київському російському педагогічному технікумі в 1930/193I навч. р. таких виявилося 75\% студентів, у І-му семестрі 193І/1932 навч. р. - 72\%, а у 2-му - 80\% ${ }^{66}$.

Найкращих студентів-ударників матеріально та морально стимулювали. Як правило, їх ушановували на врочистих зборах, приурочених до Міжнародного дня солідарності трудящих, чергової річниці більшовицької революції ${ }^{67}$ чи на вечорах ударника ${ }^{68}$. Так, у Польському педінституті у 2-му семестрі 1933/1934 навч. р. матеріально заохотили 58 ударників ${ }^{69}$. Премії отримали також студенти-ударники Вінницького єврейського (у І-му семестрі г93I/І932 навч. р. - 23)70, Дніпропетровського російського (у 2-му семестрі 1932/1933 навч. р. - 40)7, Житомирського єврейського (у 2-му семестрі 1932/1933 навч. р. - 36) 72, київських польського (в 1934/1935 навч. p. - 20)73 і російського педтехнікумів (у 1930/193г навч. p. - 674, у 1934/1935 навч. p. - 34)75.

У педагогічних навчальних закладах мала місце фальсифікація результатів індивідуального суперництва («псевдоударництво»). У травні 1933 р. на зльоті ударників Житомирського єврейського педагогічного технікуму після обговорення відповідного питання число таких «ударників» зменшилося зі І5о до $14 \mathrm{O}^{76}$.

Для того, щоб успішно виконати всі зобов'язання, окремі місяці у закладах оголошували «штурмовими» («ударні місячники»). Організовувалися «походи» щодо ліквідації академічної заборгованості. Для практичної реалізації «штурмівщини» діяли «штурмові», «буксирні» бригади ${ }^{77}$. Наприклад, у Дніпропетровському російському педтехнікумі проводили «бойові декади ліквідації академпрориву» ${ }^{78}$.

Період 1920-1930-х рр. позначений процесами суцільної атеїзації, які були складовою ідеологічної політики більшовизації студентства. Особлива увага приділялася поширенню антирелігійних поглядів. Наявні документи вказують, що студенти педагогічних освітніх закладів нацменшин у г920-х рр. були менш активними у цьому питанні, ніж їхні українські колеги. Нам удалося виявити скупі дані про функціонування осередку Спілки войовничих безбожників (у деяких джерелах - Спілки войовничих безвірників, СВБ) у Вінницькому єврейському ${ }^{79}$, гуртка «безвірників» у Дніпропетровському російському8 ${ }^{8 \circ}$ а також про запровадження у 1928/1929 навч. р.

${ }_{61}$ Держархів Дніпропетровської обл. - Ф.Р.1506. - Оп.1. - Спр.8. - Арк.45.

62 Держархів м. Києва. - Ф.Р.920. - Оп.11. - Спр.18. - Арк.9.

${ }_{63}$ Держархів Житомирської обл. - Ф.П.215. - Оп.1. - Спр.6. - Арк.7.

64 Держархів м. Києва. - Ф.Р.807. - Оп.11. - Спр.18. - Арк.13.

${ }_{65}$ Держархів Хмельницької обл. - Ф.Р.2597. - Оп.1. - Спр.6. - Арк.2 зв.

${ }_{6}^{6}$ ЦДАВО України. - Ф.166. - Оп.10. - Спр.1490. - Арк. 50; Держархів м. Києва. - Ф.Р.359. - Оп.1. - Спр.11. Арк.8; Спр.27. - Арк.4.

67 ЦДАВО України. - Ф.166. - Оп.11. - Спр.149. - Арк.54.

6 Там само. - Спр.150. - Арк.6.

69 Держархів м. Києва. - Ф.Р.920. - Оп.11. - Спр.18. - Арк.9.

${ }^{70}$ ЦДАВО України. - Ф.166. - Оп.10. - Спр.1495. - Арк.70.

71 Там само. - Оп.11. - Спр.326. - Арк.31.

72 Там само. - Арк.94.

73 Держархів м. Києва. - Ф.Р.807. - Оп.11. - Спр.18. - Арк.13.

74 Там само. - Ф.Р.359. - Оп.1. - Спр.11. - Арк.8.

75 Там само. - Спр.135. - Арк.17.

${ }^{76}$ ЦДАВО України. - Ф.166. - Оп.11. - Спр.326. - Арк.94.

77 Вища школа Української РСР за 50 років. - К., 1967. - С.216.

78 ЦДАВО України. - Ф.166. - Оп.11. - Спр.326. - Арк.30.

79 Держархів Вінницької обл. - Ф.П.29. - Оп.1. - Спр.430. - Арк.24.

80 Держархів Дніпропетровської обл. - Ф.П.7. - Оп.1. - Спр.1489. - Арк.10. 
«обов’язкового» антирелігійного семінару для третьокурсників Київського польського педтехнікумів ${ }^{81}$. Однак ідеї атеїзму, пропаговані більшовиками, не здобували широкого відгуку серед молоді. Зафіксовано випадки, коли студенти підтримували педагогів, котрі мали релігійні переконання. Наприклад, викладачі Дніпропетровського російського педагогічного технікуму Є.Добровольський, П.Левітов, В.Левітов, Чернявський у лютому 1929 р. відмовилися підписати петицію про закриття місцевої церкви й хоральної синагоги. Їхній приклад наслідували Іо студентів III курсу ${ }^{82} .5$ березня цей інцидент був на порядку денному загальних зборів закладу, де присутні під тиском влади «затаврували» дії викладачів. Серед виступальників були студенти Опалатенко, Мустяца, Тисячник, Шкляр, Промікс, Табунов. Мустяца, зокрема, зазначив: «У радянській владі не примушують, вірити чи не вірити, але в Конституції сказано, що церква відокремлена від держави чи школи. Коли випускають з педтехнікуму педагога з релігійними поглядами - це злочин, справжнього педагога не може бути при наявності релігійних викладачів». Представник Окружного бюро пролетарського студентства Циплаков звернув увагу на небезпеку поширення релігійних вірувань серед молоді: «Педагоги повинні бути марксистами, педагогіка і релігійність ніяк не в’яжуться [...] Треба поставити завдання, аби в наших школах виховувалися студенти в антирелігійному дусі; ви знаєте, яку велику роль відіграє релігія» ${ }^{83}$.

У $1930-x$ рр. антирелігійну роботу було активізовано. Осередки СВБ виникли в Польському педінституті ${ }^{84}$, Житомирському єврейському ${ }^{85}$ та Київському російському педтехнікумах ${ }^{86}$. У цих закладах, окрім осередку спілки, діяли ще й атеїстичні гуртки «Безвірник» ${ }^{87}$. Такі самі гуртки працювали у Проскурівському ${ }^{88}$, Київському польському педагогічних технікумах ${ }^{89}$.

Влада мобілізовувала студентів до участі у загальнодержавних заходах. Вони брали участь у святах, зокрема річницях більшовицької революції, Міжнародному дні солідарності трудящих ${ }^{\circ \circ}$ (наприклад, в Одеському німецькому педінститутіэг, Київському російському педтехнікумі ${ }^{92}$ ). Проводилися «Ленінські дні» (Київський польський педагогічний технікум ${ }^{93}$ ), дні пам’яті К.Маркса. Щодо останнього, то у Вінницькому єврейському педтехнікумі I4 березня 1933 р. цій події приурочили теоретичну «одноденку» на теми: «Діалектичний матеріалізм у вченні Карла Маркса», «Карл Маркс про диктатуру пролетаріату», «К.Маркс і єврейське питання». Того ж дня відбулися врочисті збори, на які прибули й учителі єврейських шкіл. Було організовано виставку літератури, присвячену мислителю. Викладачів і студентів зобов'язували брати участь в урочистостях на підшефних місцевих підприємствах, у колгоспах ${ }^{94}$. Аналогічні врочистості відбулися в Київському російському педтехнікумі 95 .

${ }_{81}$ ЦДАГО України. - Ф.1. - Оп.20. - Спр.2930. - Арк.31.

82 Держархів Дніпропетровської обл. - Ф.П.7. - Оп.1. - Спр.1489. - Арк.2, 41.

83 Там само. - Арк.70-71.

84 Держархів м. Києва. - Ф.Р.920. - Оп.11. - Спр.18. - Арк.75 зв.

85 Держархів Житомирської обл. - Ф.П.215. - Оп.1. - Спр.6. - Арк.7.

86 Держархів м. Києва. - Ф.Р.359. - Оп.1. - Спр.27. - Арк.6; Спр.67. - Арк.40, 96.

87 ЦДАВО України. - Ф.166. - Оп.10. - Спр.1490. - Арк.51; Держархів м. Києва. - Ф.Р.359. - Оп.1. - Спр.27. - Арк.7; Спр.67. - Арк.96; Ф.Р.920. - Оп.11. - Спр.18. - Арк.8.

88 Держархів Хмельницької обл. - Ф.Р.2597. - Оп.1. - Спр.6. - Арк.5 зв.

89 ЦДАВО України. - Ф.166. - Оп.10. - Спр.1490. - Арк.35.

9 Держархів Вінницької обл. - Ф.П.249. - Оп.1. - Спр.15. - Арк.14-15.

91 Держархів Одеської обл. - Ф.Р.1561. - Оп.1. - Спр.36. - Арк.24 зв.

92 Держархів м. Києва. - Ф.Р.359. - Оп.1. - Спр.135. - Арк.20.

${ }_{93}$ ЦДАВО України. - Ф.166. - Оп.10. - Спр.1490. - Арк.35.

94 Там само. - Оп.11. - Спр.326. - Арк.91.

95 Держархів м. Києва. - Ф.Р.359. - Оп.1. - Спр.69. - Арк.7. 
Ідеологічним настановам партії було підпорядковано всю громадську діяльність студентської молоді, що значною мірою заважало їй критично оцінювати реальний стан речей. Поступово охоплюваність студентства громадською роботою зростала. У Польському педінституті у 2-му семестрі 1933/1934 навч. р. в ній брали участь $87,5 \%$ слухачів ${ }^{96}$, у Київському російському педтехнікумі в 1930/1931 навч. р. - 70\%97.

Виконання різних доручень призводило до перевантаження громадською роботою, що, своєю чергою, позначалося на суто навчальних показниках. Це спонукало політбюро ЦК КП(б)У в постанові від 28 січня 1928 р. зауважити: «Враховуючи, що надмірне громадське навантаження студентів негативно впливає на успішне навчання, дати директиву як по лінії партії, так і по лінії наркомосу про те, щоб громадські, партійні та комсомольські доручення, котрі покладалися на студентів, не були б на шкоду основним заняттям студентів й успішності навчальної роботи»98. Наявні факти свідчать, що це розпорядження не завжди бралося до уваги. У Польському педінституті у 2-му семестрі 1933/1934 навч. р. по одному навантаженню мали 82,4\%, по два - 4,9\%. Окремі активісти мали ще більше навантажень ${ }^{99}$.

Водночас в деяких педтехнікумах громадська робота була менш популярною. Наприклад, із Дніпропетровського російського повідомлялося, що в 1928/1929 навч. р. студентство ії майже не проводило ${ }^{\text {1о0 }}$.

У 1920-1930-х рр. створювалися студентські організації, зокрема профспілкові, які насправді керувалися інтересами не студентів, а Наркомату освіти республіки та адміністрацій закладів. Профкоми приділяли увагу «політичному вихованню», ідеологічній роботі, а не відстоюванню прав молоді. Відсоток студентів, членів профспілок, невпинно зростав. Так, у Дніпропетровському російському педтехнікумі в 1928/1929 навч. р. членством у профспілці «Робос» і комітеті незаможних селян (своєрідна профспілка для студентів вихідців із села) загалом було охоплено 53,1\% студентів ${ }^{\text {IоI }}$, у Преславському болгарському в 1929/1930 навч. р. - 36,9\% $\%^{\text {102 }}$, у Київському російському в 1933/1934 навч. p. - 83,9\% $\%^{\text {103 }}$.

Партійне керівництво створювало й підтримувало (організаційно та фінансово) лояльні, підконтрольні громадські організації. Найбільш масовими були осередки Тсоавіахім, які функціонували, зокрема, у Польському педінституті ${ }^{104}$,

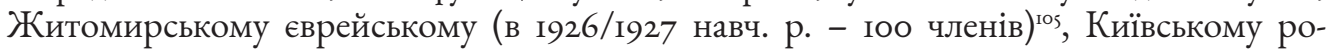
сійському ${ }^{106}$, Преславському болгарському (на початку г93о р. - 198 членів) ${ }^{107}$, Проскурівському польському педтехнікумах ${ }^{108}$. При них діяли стрілецькі гуртки, членів яких готували до складання нормативів. У Житомирському єврейському педагогічному технікумі впродовж вересня - грудня 1935 р. нормативи на отримання значка «Ворошиловський стрілець» виконали 7 осіб, «Готовий до праці й оборони» - 30 ${ }^{\text {109. }}$ У $1933 /$ г934 навч. p. 45 гуртківців Проскурівського польського педтехнікуму здобули

${ }_{6}$ Там само. - Ф.Р.920. - Оп.11. - Спр.18. - Арк.7.

${ }_{77}$ Там само. - Ф.Р.359. - Оп.1. - Спр.11. - Арк.8.

98 Див.: Кліцаков І.О. Педагогічні кадри України (1917-1937 рр.). - С.103.

99 Держархів м. Києва. - Ф.Р.920. - Оп.11. - Спр.18. - Арк.7.

100 Держархів Дніпропетровської обл. - Ф.П.7. - Оп.1. - Спр.1489. - Арк.126.

${ }_{101}$ Там само. - Арк.47.

${ }^{102}$ ЦДАВО України. - Ф.166. - Оп.10 - Спр.825.- Арк.150.

${ }_{103}$ Держархів м. Києва. - Ф.Р.359. - Оп.1. - Спр.67. - Арк.83.

${ }_{104}$ Там само. - Ф.Р.920. - Оп.11. - Спр.18. - Арк.8.

${ }_{105}$ Держархів Житомирської обл. - Ф.П.211. - Оп.1. - Спр.10. - Арк.40; Ф.П.215. - Оп.1. - Спр.6. - Арк.7; Ф.Р.266. Оп.1. - Спр.167. - Арк.221.

${ }^{106}$ ЦДАВО України. - Ф.166. - Оп.10. - Спр.1490. - Арк.51; Держархів м. Києва. - Ф.Р.359. - Оп.1. - Спр.27. - Арк.6; Спр.67. - Арк.96.

${ }_{107}$ ЦДАВО України. - Ф.166. - Оп.10. - Спр.825. - Арк.50, 150.

108 Держархів Хмельницької обл. - Ф.Р.2597. - Оп.1. - Спр.6. - Арк.5 зв.

109 Держархів Житомирської обл. - Ф.П.215. - Оп.1. - Спр.6. - Арк.7. 
третю стрілецьку категорію ${ }^{\text {по }}$ У І-му семестрі 1934/І935 навч. р. нормативи складали 35 чоловіків і г5 жінок, з яких третю категорію присвоїли, відповідно, 20 та 2 особам". У Польському педінституті в 1933/1934 навч. р. гуртківці втягнули до підготовки зі складання нормативів усіх 355 студентів вишу. Із них І2о виконали нормативи «ворошиловського стрільця», а І 43 - на значок «ГПО» ${ }^{\text {II2 }}$.

Складали нормативи і члени фізкультурних гуртків. Наприклад, у 1933/1934 навч. p. 40 гуртківців Проскурівського польського педтехнікуму виконали нормативи на значок «ГПО» ${ }^{113}$. Гуртки функціонували також у Дніпропетровському російському ${ }^{\mathrm{II}}$, Житомирському єврейськомугі, Київському російському (в 1933/1934 навч. p. - г7 членів $)^{\text {16}}$, Преславському болгарському закладах ${ }^{117}$. Усіх гуртківців і негуртківців в обов'язковому порядку зобов'язували брати участь у фізкультурних парадах. 3І травня 1936 р. директор Одеського німецького педінституту насмілився скасувати це правило, зауваживши, що участь у них мала бути добровільною ${ }^{\text {п8. }}$

Свої результати члени гуртків демонстрували на змаганнях, у конкурсах-оглядах. Так, у 1933/1934 навч. р. Польський педінститут у конкурсі-огляді на найкращу фізкультроботу серед вишів республіки було визнано одним із зразкових ${ }^{\text {I19 }}$.

У педтехнікумах нацменшин діяли осередки Міжнародної організації допомоги робітникам, зокрема у Житомирському ${ }^{120}$ й Одеському єврейських ${ }^{121}$, Київському російському $^{\text {122 }}$, Преславському болгарському (в 1929/1930 навч. р. - 63 члени) $)^{\text {123}}$, Проскурівському

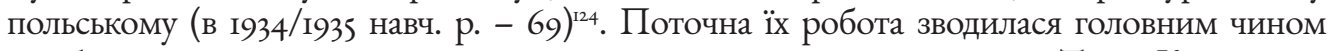
до збору коштів на допомогу переслідуваним за кордоном трудящим. Так, у Київському польському педтехнікумі в 1931/1932 навч. р. створювали бригади для організації зборів коштів на допомогу політв'язням у Польщі ${ }^{125}$. Проводилися тематичні вечори та «інтернаціональні дні» (Житомирський єврейський педагогічний технікум ${ }^{126}$ ).

Для боротьби з дитячою безпритульністю створювалися осередки громадської організації «Друзі дітей» (наприклад, у Преславському болгарському педтехнікумі в 1929/1930 навч. р. - 74 члени $)^{127}$. Діяли філії Товариства Червоного Хреста, зокрема, у Житомирському єврейському ${ }^{128}$, Преславському болгарському

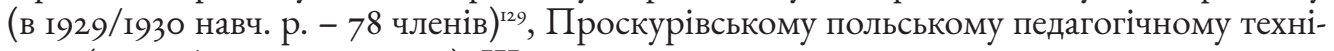
кумі (в 1934/1935 навч. р. - 58). Що стосується останнього, то тут працював також гурток із надання першої медичної допомоги (зо осіб) $)^{130}$.

\footnotetext{
${ }_{110}$ Держархів Хмельницької обл. - Ф.Р.2597. - Оп.1. - Спр.1. - Арк.252, 262.

${ }_{111}^{11}$ Там само. - Спр.10. - Арк.10.

112 Держархів м. Києва. - Ф.Р.920. - Оп.11. - Спр.18. - Арк.8, 79 зв.

113 Держархів Хмельницької обл. - Ф.Р.2597. - Оп.1. - Спр.1. - Арк.62.

114 Держархів Дніпропетровської обл. - Ф.П.7. - Оп.1. - Спр.1489. - Арк.126.

115 Держархів Житомирської обл. - Ф.П.215. - Оп.1. - Спр.6. - Арк.7.

${ }_{116}$ ЦДАВО України. - Ф.166. - Оп.10. - Спр.1490. - Арк.51; Держархів м. Києва. - Ф.Р.359. - Оп.1. - Спр.27. - Арк.7; Спр.67. - Арк.40, 96.

${ }_{117}$ ЦДАВО України. - Ф.166. - Оп.10. - Спр.825. - Арк.50.

118 Держархів Одеської обл. - Ф.Р.1561. - Оп.1. - Спр.15. - Арк.48.

119 Держархів м. Києва. - Ф.Р.920. - Оп.11. - Спр.18. - Арк.8, 79 зв.

120 Держархів Житомирської обл. - Ф.П.215. - Оп.1. - Спр.6. - Арк.7; Ф.Р.266. - Оп.1. - Спр.167. - Арк.221.

${ }^{121}$ ЦДАВО України. - Ф.166. - Оп.5. - Спр.264. - Арк.44.

122 Там само. - Оп.10. - Спр.1490. - Арк.51; Держархів м. Києва. - Ф.Р.359. - Оп.1. - Спр.27. - Арк.6; Спр.67. Арк.96.

${ }^{123}$ ЦДАВО України. - Ф.166. - Оп.10. - Спр.825. - Арк.50, 150.

124 Держархів Хмельницької обл. - Ф.Р.2597. - Оп.1. - Спр.6. - Арк.5 зв.

125 ЦДАВО України. - Ф.166. - Оп.10. - Спр.1490. - Арк.34.

126 Держархів Житомирської обл. - Ф.П.215. - Оп.1. - Спр.2. - Арк.7.

${ }^{127}$ ЦДАВО України. - Ф.166. - Оп.10. - Спр.825. - Арк.50, 150.

${ }_{128}$ Держархів Житомирської обл. - Ф.П.215. - Оп.1. - Спр.6. - Арк.7.

${ }^{129}$ ЦДАВО України. - Ф.166. - Оп.10. - Спр.825. - Арк.50, 150.

130 Держархів Хмельницької обл. - Ф.Р.2597. - Оп.1. - Спр.6. - Арк.5 зв.
} 
У навчальних закладах педагогічного профілю діяли осередки Всеукраїнського товариства по земельному облаштуванню трудящих євреїв «Озет». Логічно, що «озетівці» працювали і в єврейських педтехнікумах, зокрема в Одеському ${ }^{131}$ та Житомирському. У 1935 р. останній за зразкову роботу по лінії товариства «Озет» отримав перехідний Червоний прапор, подяку від спілки «Робос» і відділу народної освіти. У цьому ж закладі функціонував осередок товариства «Євкульт» ${ }^{132}$. У 1931/1932 навч. р. Іо озетівців Одеського єврейського педагогічного технікуму «самомобілізувалися» до Біробіджана (центр Єврейської автономної області РСФРР) Цікаво, що осередки «Озет» діяли й у педтехнікумах інших національних меншин, наприклад у Київському російському ${ }^{134}$, Проскурівському польському ${ }^{135}$.

У педагогічних закладах працювали осередки організації «Друзів радіо» (радіогуртки), зокрема у Житомирському єврейському, який у 1935 р. за зразкову роботу отримав від радіовузла преміювання у вигляді радіоустановки ${ }^{136}$. У Польському педінституті у 2-му семестрі 1933/1934 навч. р. діяв гурток із вивчення авіамотору, до якого входили 17 осіб ${ }^{137}$.

Процеси розбудови вищої школи в комуністичному дусі, побут та настрій студентів, їхня участь в ідеологічній роботі серед населення відображалися в періодичній пресі навчальних закладів. Так, видавався «Польський журнал Київського польського педтехнікуму» ${ }^{138}$. Натомість Польський педінститут ${ }^{139}$, Вінницький ${ }^{140}$ і Житомирський єврейські ${ }^{141}$, Київський російський ${ }^{142}$, Проскурівський польський педагогічні технікуми ${ }^{143}$ обмежувалися випуском стінгазет. У першому з цих закладів за 2-й семестр 1933/1934 навч. р. було підготовлено 9 загальноінститутських, I4 факультетських, го гуртожитських стінних газет, а також 9 бюлетенів ${ }^{144}$. У Проскурівському польському педтехнікумі в 1933/1934 навч. р. створено І6 загальнотехнікумівських газет, двічі на місяць публікувалися курсові ${ }^{145}$. У Київському російському педагогічному технікумі в 1934/1935 навч. р. видрукували 86 чисел загальнотехнікумівської, курсових і групових газет $^{146}$. У вересні - грудні 1936 р. у Житомирському єврейському педтехнікумі вийшли 4 загальнотехнікумівських і 26 курсових газет ${ }^{\mathrm{I47}}$.

Навколо газет гуртувався актив студентських кореспондентів (студкорів), які об'єднувалися у студкорівські гуртки. Такий невеличкий осередок діяв у 1933/1934 навч. р. в Київському російському педтехнікумі, який об'єднував 5 членів ${ }^{148}$.

Студентів зобов'язували передплачувати пресу - як загальносоюзну, так і республіканську. Зокрема в Київському російському педтехнікумі в 1931/1932 навч. p. молодь передплачувала I58 примірників газет і журналів, з яких 20\% мали педагогічний

${ }^{131}$ ЦДАВО України. - Ф.166. - Оп.5. - Спр.264. - Арк.44.

${ }_{132}$ ЦДАГО України. - Ф.7. - Оп.1. - Спр.1079. - Арк.255; Держархів Житомирської обл. - Ф.Р.266. - Оп.1. Спр.167. - Арк.221.

${ }_{133}$ ЦДАВО України. - Ф.166. - Оп.10. - Спр.798. - Арк.20.

${ }_{134}$ Там само. - Спр.1490. - Арк.5.

${ }^{135}$ Держархів Хмельницької обл. - Ф.Р.2597. - Оп.1. - Спр.6. - Арк.5 зв.

${ }^{136}$ ЦДАГО України. - Ф.7. - Оп.1. - Спр.1079. - Арк.255.

${ }_{137}$ Держархів м. Києва. - Ф.Р.920. - Оп.11. - Спр.18. - Арк.79 зв.

138 Лаврут О. Студентська преса в УСРР періоду 20-х рр. ХХ ст. // Гілея. - Вип.28. - К., 2009. - С.50.

139 Держархів м. Києва. - Ф.Р.920. - Оп.11. - Спр.18. - Арк.9.

${ }^{140}$ ЦДАВО України. - Ф.166. - Оп.10. - Спр.1495. - Арк.68.

${ }_{141}$ Держархів Житомирської обл. - Ф.П.215. - Оп.1. - Спр.6. - Арк.6.

${ }_{142}$ Держархів м. Києва. - Ф.Р.359. - Оп.1. - Спр.67. - Арк.4, 96.

143 Держархів Хмельницької обл. - Ф.Р.2597. - Оп.1. - Спр.1. - Арк.253зв., 262; Спр.6. - Арк.3 зв.

${ }_{144}$ Держархів м. Києва. - Ф.Р.920. - Оп.11. - Спр.18. - Арк.9.

${ }_{145}$ Держархів Хмельницької обл. - Ф.Р.2597. - Оп.1. - Спр.1. - Арк.253 зв., 262; Спр.6. - Арк.3 зв.

${ }_{146}$ Держархів м. Києва. - Ф.Р.359. - Оп.1. - Спр.67. - Арк.4, 96.

${ }_{147}$ Держархів Житомирської обл. - Ф.П.215. - Оп.1. - Спр.6. - Арк.6.

${ }_{148}$ Держархів м. Києва. - Ф.Р.359. - Оп.1. - Спр.67. - Арк.40. 
профіль, по го\% - технічний та військовий, решта - партійні й комсомольські видан-

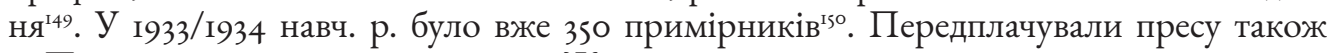
у Проскурівському польському⿰氵⿱⺊口灬口,, Житомирському єврейському педагогічних технікумах $^{152}$. Крім того, житомирські студенти в 1935 р. виписали ще 200 примірників шеститомника праць В.Леніна та 55 примірників однотомного зібрання В.Леніна і Й.Сталіна ${ }^{153}$. Студентів зобов’язували щоденно читати газети ${ }^{154}$.

Молодь залучали до участі в різних загальнодержавних кампаніях, зокрема зі збору коштів на господарські потреби загальнодержавного значення. Студенти Вінницького єврейського педтехнікуму в 193I/1932 навч. р. збирали гроші серед жителів міста, які передбачалося спрямувати на виконання першої п'ятирічки ${ }^{155}$. Вихованці Преславського болгарського реалізували позику «П'ятирічка за чотири роки» ${ }^{156}$. Таку ж роботу проводила й молодь Житомирського єврейського ${ }^{157}$, Проскурівського польського педагогічних технікумів ${ }^{158}$. Студентство, зокрема Київського польського закладу, брало участь у зборах коштів на потреби оборони ${ }^{159}$.

Залучалася студентська молодь і до інших видів робіт. Комсомольці Київського польського педтехнікуму в 1934/1935 навч. р. після постанови ЦК партії про ліквідацію карткової системи на хліб брали участь у перевірці роботи хлібних магазинів ${ }^{160}$. Слухачі Вінницького єврейського закладу допомагали у проведенні товариством «Озет» переселенської кампанії ${ }^{161}$. Вихованці Проскурівського польського педагогічного технікуму складали списки виборців, організовували агітбригади, створювали інформаційні куточки у приміщеннях, де проходили вибори. У 1933/1934 навч. р. одного зі студентів цього закладу обрали депутатом міської ради ${ }^{162}$.

Важливим напрямом громадської діяльності студентів була їхня робота у селах для реалізації так званої «культзмички міста й села». Студенти Вінницького єврейського педтехнікуму працювали в підшефному с. Юзвин ${ }^{163}$, Преславського болгарського у с. Данівка та радгоспі «Вільний» ${ }^{164}$, Проскурівського польського - у с. Шаровечка ${ }^{165}$, Хортицького німецького - у сільськогосподарській комуні «Майбуття» с. Хортиці ${ }^{166}$.

Для підготовки студентської молоді до роботи на селі проводилися відповідні заняття й семінари. Наприклад, у Вінницькому єврейському педагогічному технікумі в I930 р. на курсових зборах обговорювалися питання «Чергові завдання політики партії на селі», директиви РНК УСРР та місцевих органів про весняну посівну кампанію. Випускалися стінгазети, в яких висвітлювалася робота у селах, уміщувалися новини з

\footnotetext{
${ }^{149}$ ЦДАВО України. - Ф.166. - Оп.10. - Спр.1490. - Арк.52.

150 Держархів м. Києва. - Ф.Р.359. - Оп.1. - Спр.67. - Арк.96.

151 Держархів Вінницької обл. - Ф.П.457. - Оп.1. - Спр.444. - Арк.155.

152 ЦДАВО України. - Ф.166. - Оп.9. - Спр.1796. - Арк.8.

153 Держархів Житомирської обл. - Ф.П.215. - Оп.1. - Спр.6. - Арк.5.

${ }^{154}$ ЦДАГО України. - Ф.7. - Оп.1. - Спр.1079. - Арк.255.

155 ЦДАВО України. - Ф.166. - Оп.10. - Спр.1495. - Арк.69.

156 Там само. - Спр.825. - Арк.152.

157 Держархів Житомирської обл. - Ф.П.215. - Оп.1. - Спр.5. - Арк.9; Колектив педтехнікуму виконав завдання IV кварталу // За більшовицьку молодь (Житомир). - 1933. - 21 жовтня. - №9. - С.2.

158 Держархів Вінницької обл. - Ф.П.457. - Оп.1. - Спр.444. - Арк.155.

159 ЦДАВО України. - Ф.166. - Оп.10. - Спр.1490. - Арк.34.

160 Держархів м. Києва. - Ф.Р.807. - Оп.11. - Спр.18. - Арк.13.

${ }^{161}$ ЦДАВО України. - Ф.166. - Оп.10. - Спр.1495. - Арк.69.

162 Держархів Хмельницької обл. - Ф.Р.2597. - Оп.1. - Спр.6. - Арк.5.

${ }_{163}$ ЦДАВО України. - Ф.166. - Оп.10. - Спр.1495. - Арк.69; Держархів Вінницької обл. - Ф.П.29. - Оп.1. Спр.620. - Арк.165.

${ }_{164}$ ЦДАВО України. - Ф.166. - Оп.10. - Спр.825. - Арк.50.

165 Держархів Вінницької обл. - Ф.П.457. - Оп.1. - Спр.444. - Арк.155; Держархів Хмельницької обл. - Ф.Р.2597. Оп.1. - Спр.1. - Арк.148, 253; Спр.6. - Арк.262.

166 Держархів Запорізької обл. - Ф.П.7. - Оп.1. - Спр.130. - Арк.27.
} 
сільської місцевості. Студенти облаштували куточок посівної кампанії з гаслами, вирізками з газет із постановами уряду, планами участі в посівній кампані1 ${ }^{167}$.

Особливо широко влада залучала молодь до хлібозаготівель. Для проведення практичної роботи студентів об'єднували у бригади. Так, у 1932/1933 навч. р. у відповідних заходах узяли участь 29 бригад Дніпропетровського російського педтехнікуму ${ }^{168}$.

Більшість фактів указують на те, що пріоритетною формою роботи у сільській місцевості було надання допомоги селянам під час весняної посівної кампанії. Зокрема в 1931/1932 навч. р. 2 бригади студентів Одеського єврейського педагогічного технікуму трудилися в підшефному колгоспі «Сільхозар ${ }^{169}$. У 1934/1935 навч. р. 8 студентських бригад Проскурівського польського проводили шефську роботу у с. Шаровечка ${ }^{170}$.

Завершували річний цикл осіння збиральна й посівна кампаніі. У І931/1932 навч. p. до Калініндорфського району було відряджено на місяць $о$ студентів Вінницького єврейського педтехнікуму - для «ліквідації прориву у копанні буряків, м’ясозаготівлі, сінозаготівлі». Крім того, усі вихованці закладу впродовж 5 днів копали буряки у c. Стадниця ${ }^{171}$. Одночасно у селах трудилися I5 студентів Одеського єврейського педагогічного технікуму ${ }^{172}$. Виконувала молодь у селах і ряд інших робіт. Так, слухачі Харківського єврейського в єврейських колоніях Херсонщини й Маріупольщини провели кампанії зі збору продподатку та організації землеустрою ${ }^{173}$.

Студентів залучали до організації у селах політико-освітньої роботи. Найпоширенішими формами було виголошення доповідей (Проскурівський польський $)^{174}$, організація державних і «революційних» свят, залучення селян до гурткової роботи (Житомирський єврейський педтехнікуми) ${ }^{175}$.

Одним із напрямів роботи у сільській місцевості була також антирелігійна пропаганда. Студенти використовували різні форми. Наприклад, молодь Житомирського єврейського педагогічного технікуму випускала антирелігійну газету в колгоспі «Друкар». За дорученням міського бюро СВБ тут було організовано експозицію й фотовиставку на тему «Класова роль та шляхи ії відмирання». Слухачі Проскурівського польського педтехнікуму в 1934/1935 навч. р. провели антирелігійний вечір у с. Шаровечка ${ }^{176}$.

На селі студенти опікувалися також роботою осередків різних громадських організацій. Так, молодь Харківського єврейського педагогічного технікуму започаткувала в підшефних селах організаційні структури Доброхіму та Міжнародної організації допомоги борцям революції (МОДР $)^{177}$.

Більшу частину свого часу студенти приділяли культурно-освітній роботі серед селян. Зокрема вони обслуговували хати-читальні, дбали про поповнення фондів сільських бібліотек (вихованці Одеського ${ }^{178}$ та Харківського єврейських педтехнікумів

\footnotetext{
${ }_{167}$ Держархів Вінницької обл. - Ф.Р.3510. - Оп.1. - Спр.5. - Арк.43.

168 ЦДАВО України. - Ф.166. - Оп.11. - Спр.326. - Арк.30.

${ }_{169}$ Там само. - Оп.10. - Спр.798. - Арк.20.

170 Держархів Вінницької обл. - Ф.П.457. - Оп.1. - Спр.444. - Арк.155; Держархів Хмельницької обл. - Ф.Р.2597. Оп.1. - Спр.1. - Арк.148, 253; Спр.6. - Арк.262.

${ }^{171}$ ЦДАВО України. - Ф.166. - Оп.10. - Спр.1495. - Арк.69.

172 Там само. - Спр.798. - Арк.20.

${ }^{173}$ ЦДАВО України. - Ф.166. - Оп.5. - Спр.264. - Арк.29.

${ }_{174}$ Держархів Вінницької обл. - Ф.П.457. - Оп.1. - Спр.444. - Арк.155; Держархів Хмельницької обл. - Ф.Р.2597. Оп.1. - Спр.1. - Арк.148, 253; Спр.6. - Арк.262.

${ }^{175}$ ЦДАВО України. - Ф.166. - Оп.11. - Спр.326. - Арк.87.

176 Держархів Вінницької обл. - Ф.П.457. - Оп.1. - Спр.444. - Арк.155; Держархів Хмельницької обл. - Ф.Р.2597. Оп.1. - Спр.1. - Арк.148, 253; Спр.6. - Арк.262.

17 ЦДАВО України. - Ф.166. - Оп.5. - Спр.264. - Арк.29.

${ }_{178}$ Там само. - Арк.44 зв.
} 
надсилали літературу $\left.{ }^{179}\right)$, видавали чи допомагали видавати стінні, «польові» газети (Житомирський єврейський) $^{180}$, ставили вистави (Хортицький німецький) ${ }^{181}$. Однією 3 найбільш поширених форм масової політроботи були вечори. Так, слухачі грецького відділення Маріупольського педагогічного технікуму навесні 1930 р. у 5 грецьких селах організували вечори національної культури ${ }^{182}$. У 1935 р. Київський російський заклад провів випускний вечір, в якому взяли участь передовики-колгоспники та члени партосередку підшефного колгоспу ${ }^{183}$.

Із різних місцевостей надходили схвальні відгуки про роботу студентів на селі, частину з них заохотили. Наприклад, восени 193і р. за збір урожаю в Калініндорфському районі премію отримали 27 вихованців Вінницького єврейського педтехнікуму ${ }^{184}$. Водночас 17 березня 1935 р. на відкритих партійних зборах цього ж закладу йшлося про те, що молодь відмовлялася їхати на роботу у села ${ }^{\mathrm{I8}}$.

Студенти-педагоги брали шефство й над робітниками місцевих підприємств. Так, Вінницький єврейський технікум проводив роботу у клубах будівельників, кравців, на макаронній фабриці ${ }^{186}$, Київський російський - на кабельному заводі ${ }^{187}$, Проскурівський польський - у польському робітничому клубі ${ }^{188}$.

Основною формою роботи було виголошення доповідей. Викладачі та студенти Житомирського єврейського педтехнікуму систематично виступали на місцевих підприємствах, зокрема ім. І Травня, «Червоний чоботар», «Промкоопдерево», «Кустшвей», у колгоспі «Друкар», у клубі «Древо» ${ }^{189}$.

Певна увага приділялася проведенню на заводах і фабриках антирелігійної роботи. Наприклад, студенти Житомирського єврейського педтехнікуму в 1933 р. на фабриці ім. І Травня випустили відповідну газету, на підприємствах «Промкоопдерево», «Кустшвей» організували два гуртки «войовничих безвірників», провели радіомітинг «2-га п’ятирічка та релігія» ${ }^{190}$. У вересні - грудні 1935 р. силами викладачів і студентів цього закладу було реалізовано 25 антирелігійних вечорів на підприємствах та у школах, а також один загальноміський ${ }^{19}$. Вихованці Київського польського педагогічного технікуму восени 1931 р. організували антирелігійний вечір на заводі ім. М.Томського, облаштували тут пересувну польську бібліотеку, а також постійний лікнеп ${ }^{192}$.

Студентів залучали до шефства над підрозділами Червоної армії. Молодь Київського російського педтехнікуму працювала у полку зв’язку ${ }^{193}$. Опікувалися червоноармійцями також студенти Вінницького ${ }^{194}$ й Житомирського єврейських ${ }^{195}$, Проскурівського польського закладів ${ }^{196}$.

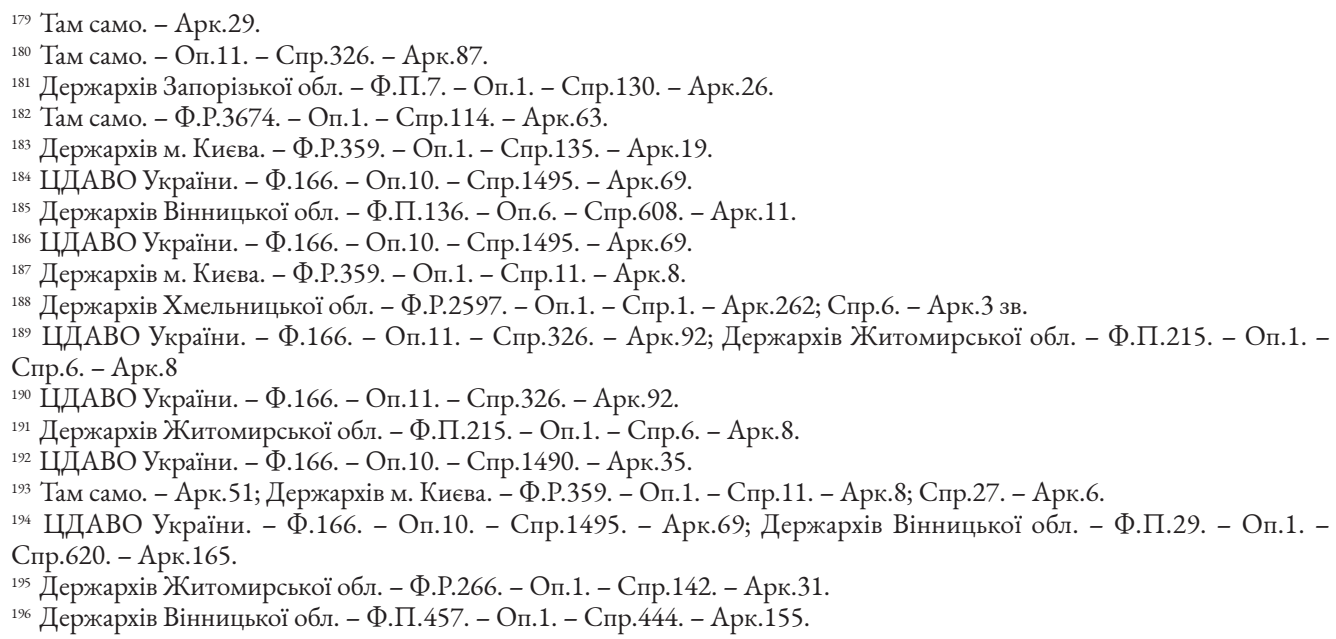


Майбутні педагоги читали для бійців і командирів лекції, доповіді на наукові та політичні теми. Студенти Одеського єврейського технікуму в 1926/1927 навч. р. виступали перед матросами Чорноморського флоту ${ }^{197}$. Слухачі Харківського єврейського закладу восени 1925 р. проводили політосвітню роботу серед дружин військовослужбовців командного складу підшефного полку, а також у «ленінських кутках» серед червоноармійців. Третьокурсники працювали як викладачі у загальноосвітній полковій школі ${ }^{198}$.

Студенти організовували відзначення революційних і державних свят, під час чого читалися доповіді, проводилися концерти, ставилися п’єси (Київський російський педтехнікум ${ }^{199}$ ), відбувалися спільні культурно-масові заходи (вечори «змички») (Одеський єврейський ${ }^{\circ 0}$ ).

Молодь допомагала військовослужбовцям створювати гуртки (Одеський єврейський педагогічний технікум $\left.{ }^{201}\right)$, випускати стінгазети, передплачували для них газети, налагодили обмін пресою (Житомирський ${ }^{202}$ та Одеський єврейські ${ }^{203}$, Проскурівський польський ${ }^{204}$ ).

Хлопці й дівчата збирали кошти для різних потреб червоноармійців, постачали їх літературою (Одеський єврейський педтехнікум ${ }^{205}$ ). У Проскурівському польському молодь організувала збір коштів для преміювання найкращих бійців ${ }^{206}$.

Установлювалося шефство над різними місцевими установами та культурно-освітніми закладами, наприклад Хортицький німецький педтехнікум - над 7-річною трудовою і профтехнічною школами ${ }^{207}$. Слухачі Харківського єврейського восени 1925 р. брали участь у роботу міського клубу ім. III Інтернаціоналу. Вони опікувалися роботою культшефської комісії, юнацької секції, учителювали у вечірній школі ${ }^{208}$. У клубі під такою ж назвою в 1925/1926 навч. р. працювали студенти Одеського єврейського педагогічного технікуму - вони організовували вечори, випускали стінгазети тощо ${ }^{209}$.

Звичайно, вихованців педзакладів мобілізовували для роботи серед піонерів. Наприклад, слухачі Житомирського єврейського технікуму в 1933 р. провели змагання серед осередків «юних безвірників» єврейських шкіл щодо найкращого проведення антирелігійної кампанії. Крім того, вони організували бесіди на антирелігійні теми в піонерському клубі гіо

Під час кампанії з ліквідації неписьменності серед дорослого населення студентство працювало в лікнепах як пропагандисти, агітатори та «ліквідатори». У боротьбі з неписьменністю брала участь молодь Житомирського ${ }^{211}$ й Одеського єврейських ${ }^{212}$, Дніпропетровського ${ }^{213}$, Київського російських педтехнікумів ${ }^{214}$. Найбільш активних

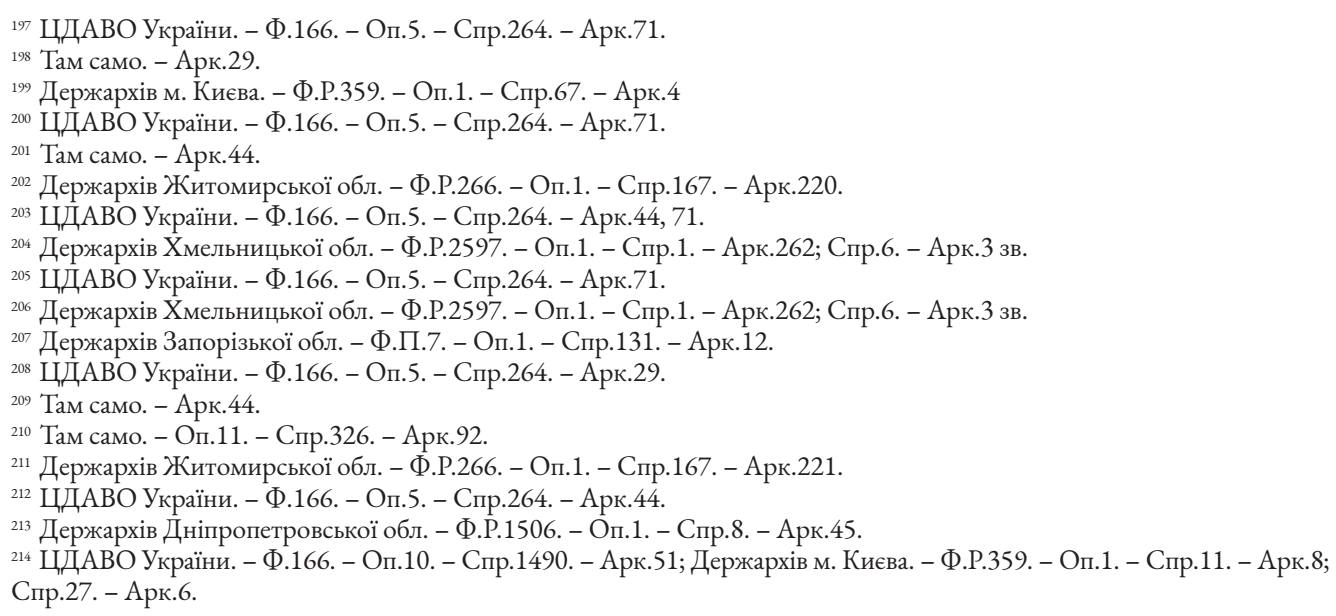


студентів-«ліквідаторів» було нагороджено значком «Геть неписьменність!». Добре працювала молодь Житомирського єврейського закладу, за що технікум у 1935 р. відзначили відповідною грамотою ${ }^{215}$.

Дехто з майбутніх педагогів не підтримували «лінію партії», «ударні темпи будівництва соціалізму», скорочення термінів навчання, негативно ставилися до вивчення ідеологічних дисциплін. Так, у 1933/1934 навч. р. студент III курсу хімічного відділення Польського педінституту Опико в гуртожитку висміював гасла радянської пропаганди, висловлювався про злиденне життя молоді тощо ${ }^{216}$. Деякі студенти сприймали смерть того чи іншого керівника держави, більшовицького діяча як сподівання на подальші позитивні зміни в державі. Так, 27 січня 1935 р. студент I курсу Вінницького єврейського педтехнікуму Штілерман говорив: «Якщо впродовж I-го року померло два керівника партії, то скільки ж помре протягом 4-х років?» ${ }^{217}$. У наказі по Одеському німецькому педінституту №42 від Іо жовтня 1934 р. йшлося про «антирадянську та контрреволюційну роботу» серед студентів, яку проводив I.Ланц, за що його відрахували з вишу. Щоправда, у чому конкретна провина цієї людини, у документі не повідомлялося ${ }^{218}$. У Польському педінституті «ворогами народу» оголосили студентів Шліфершгейна, який проходив у судово-слідчих документах як перебіжчик із Польщі, і Вацхевиха (нібито мав зв’язок зі «шпигунами» та допомагав касирові Філіповському перейти на польську територію) $)^{219}$.

Деякі джерела свідчать про опозиційні настрої студентів, спричинені іноземним чинником. На початку 1930-х рр., зокрема в Польському педінституті, почала з'являтися свастика («хрестики») та гасла на зразок: «Хай живе фашизм!» 220.

Серед студентства визрівало невдоволення економічною політикою влади. Молодь відверто заявляла про помилки у сільському господарстві, що призвело до Голодомору 1932-1933 рр. Наприклад, у 1933 р. студенти Хортицького німецького педтехнікуму, повернувшись із канікул, поширювали «нездорові» відомості про те, що «колгоспи не зможуть посіяти свою землю», «коні в колгоспі всі здохли», «колгоспники не мають хліба» ${ }^{221}$. Думки цих молодих людей підтверджує низка архівних джерел, в яких ідеться про бідування студентів. Узимку 1932-1933 рр. слухачі Преславського болгарського педагогічного технікуму отримували по г5о г хліба. Цієї мізерної пайки вони чекали по 2-3222, а студенти Маріупольського грецького закладу - навіть 4 дні $^{223}$. У Калініндорфському єврейському педтехнікумі на весь день видавалося лише по гоо-І8о г крупи на кожного вихованця ${ }^{224}$. Надзвичайно низькою була калорійність їжі в Польському педінституті ${ }^{225}$. Натомість у Хортицькому німецькому педагогічному технікумі наприкінці 1932 р. студентам відпускали по 400 г хліба ${ }^{226}$.

\footnotetext{
${ }^{215}$ ЦДАГО України. - Ф.7. - Оп.1. - Спр.1079. - Арк.255.

216 Держархів м. Києва. - Ф.Р.920. - Оп.11. - Спр.18. - Арк.35.

217 Держархів Вінницької обл. - Ф.П.136. - Оп.6. - Спр.608. - Арк.11, 13; Настрої та поведінка населення Поділля в умовах сталінської революції «згори»: 1928-1940: Зб. док. та мат. / Упор.: Р.Подкур, В.Васильєв, П.Кравченко, В.Петренко. - К., 2013. - С.333.

${ }^{218}$ Держархів Одеської обл. - Ф.Р.1561. - Оп.1. - Спр.1. - Арк.36 зв.

${ }_{219}$ Двірна К. Створення і ліквідація Польського педагогічного інституту... - С.152-153.

${ }_{220}$ ЦДАГО України. - Ф.1. - Оп.20. - Спр.6451. - Арк.3; Рябченко О. Студенти радянської України 19201930-х рр. ... - С.214.

${ }^{221}$ ЦДАВО України. - Ф.166. - Оп.11. - Спр.326. - Арк.39.

222 Там само. - Оп.10. - Спр.825. - Арк.8.

223 Там само. - Оп.11. - Спр.326. - Арк.9.

${ }_{224}$ Там само. - Арк.1.

225 Держархів м. Києва. - Ф.Р.920. - Оп.11. - Спр.18. - Арк.77.

226 Чирко Б.В. Національні меншини в Україні (20-30 рр. ХХ ст.). - К., 1995. - С.108.
} 
У $1932-1933$ рр. зросла вартість харчування, зокрема слухачі Житомирського єврейського педтехнікуму харчувалися за г руб. 30 коп. у день ${ }^{227}$. Дефіцит їжі штовхав молодь на відчайдушні вчинки. Так, частина студентів Проскурівського польського педтехнікуму підхарчовувалися у саду військкомату, що знаходився поряд із закладом. Кількох крадіїв передали до райвідділу міліції ${ }^{28}$.

У декількох навчальних педзакладах нацменшин мали місце прояви антисемітизму. У Київському російському педагогічному технікумі в 1930/1931 навч. р. один зі студентів заявив, що не хоче працювати у складі бригади, де «самі жиди» 229 . У Київському польському в 1929 р. на комсомольських зборах, коли обговорювали антисемітські «вибрики» студента інституту народного господарства Голубцова, комсомолець Бега виступив на його захист. У цьому ж закладі відзначалися прояви «польського націоналізму» і «шляхетського гонору» ${ }^{230}$. В антисемітизмі звинувачували також студентів Польського педінституту ${ }^{231}$.

Водночас серед поодиноких студентів-євреїв мав місце «нездоровий націоналістичний настрій». У листопаді 1934 р. вихованка Житомирського єврейського педтехнікуму Остайгер у загальноміському розподільнику хліба звернулася до одновірців: «Підемо, поки ці “арейлім” (образливий вислів щодо неєвреїв - Aвm.) не одержали хліба, ми нічого не доб'ємося» ${ }^{232}$.

Частина молоді «викривала» наставників - «ворогів народу». У 1936 р. студенти Одеського німецького педінституту Б.Тичинський, В.Пельцер, О.Вольф, А.Ніккелеш, Лейнер, проявивши «політичну пильність», «сигналізували» про викладача Політкинша, котрий «протягував контрреволюційно-троцькістські» ідеї ${ }^{233}$.

«Антирадянських», «соціально чужих» студентів відраховували, а згодом і репресували. Так, у Польському інституті соціального виховання у 193I/1932 навч. р. заарештували го слухачів (Панька, Корицького, Мулька, Гожкова, Павліковського та ін. ${ }^{234}$. У березні 1933 р. Польський педінститут залишили 40 осіб 235 . Восени 1933 р., за повідомленням віце-консула II Речіпосполитої в Києві П.Курніцького, із цього закладу та Київського польського педтехнікуму було виключено І5о студентів старших курсів $^{236}$. У 1934/1935 навч. р. із 512 студентів 84 були визнані «контрреволюціонерами» ${ }^{237}$. У Київському російському педагогічному технікумі в 1933/1934 навч. р. як «класово чужий елемент» «виявили себе» $4^{238}$, а в I-му семестрі 1934/1935 навч. p. - 2 вихованців ${ }^{239}$. У Київському польському закладі в 1934/1935 навч. р. до такої категорії було віднесено 7 студентів ${ }^{240}$. Одеський німецький педінститут у $1934-1936$ рр. не з власної волі

\footnotetext{
${ }_{227}^{22}$ ЦААВО України. - Ф.166. - Оп.11. - Спр.326. - Арк.69.

${ }_{228}$ Гринько А.І. Діяльність закладів середньо-спеціальної, професійно-технічної та партійної освіти Хмельниччини під час голодомору 1932-1933 рр. // Освіта, наука і культура на Поділлі / [О.М.Завальнюк (відп. ред.), Л.В.Баженов та ін.]. - Т.10. - Кам'янець-Подільський, 2007. - С.315.

229 Держархів м. Києва. - Ф.Р.359. - Оп.1. - Спр.11. - Арк.7.

${ }^{230}$ ЦДАГО України. - Ф.1. - Оп.20. - Спр.2930. - Арк.32; Мірошніченко. Уславлений технікум (Ще про польпедтехнікум у Київі) // Студент революції (Харків). - 1929. - №5/6. - С.30.

${ }_{231}^{231}$ ЦАВО України. - Ф.166. - Оп.10. - Спр.1529. - Арк.17, 33; ЦДАГО України. - Ф.1. - Оп.20. - Спр.6641. Арк.140.

232 Держархів Житомирської обл. - Ф.П.215. - Оп.1. - Спр.2. - Арк.8.

${ }_{233}$ Держархів Одеської обл. - Ф.Р.1561. - Оп.1. - Спр.15. - Арк.46.

${ }^{234}$ ЦДАВО України. - Ф.166. - Оп.10. - Спр.1529. - Арк.17, 24.

${ }_{235}^{23}$ Горбуров К. Переддень «Великого терору» у Польському педагогічному інституті у Києві // Політичні репресії в Українській РСР 1937-1938 рр.: дослідницькі рефлексії та інтерпретації: До 75-річчя «Великого терору» в СРСР: Мат. Всеукр. наук. конф. - К., 2013. - С.93.

${ }_{236}$ Там само. - С.95.

${ }_{237}$ Двірна К. Створення і ліквідація Польського педагогічного інституту... - С.152; Єфіменко Г.Г. Національнокультурна політика ВКП(б) щодо радянської України (1932-1938). - К., 2001. - С.190.

${ }^{238}$ Держархів м. Києва. - Ф.Р.359. - Оп.1. - Спр.67. - Арк.84.

239 Там само. - Спр.137. - Арк.5.

${ }^{240}$ Держархів м. Києва. - Ф.Р.807. - Оп.11. - Спр.18. - Арк.1.
} 
залишили Г.Гейдек, М.Кіфель ${ }^{241}$, Улітін ${ }^{242}$, Л.Лерх, Р.Крейс ${ }^{243}$. Чимало студентів-заочників цього ж вишу відрахували як таких, що не забезпечили «комуністичного виховання дітей». Серед них - О.Греклер, Р.Кох, С.Кольба ${ }^{244}$, Ф.Тальнер ${ }^{245}$, Вебер, Вейланд, Д.Рейсмер ${ }^{246}$, А.Брендель ${ }^{247}$ та ін. Як правило, відрахування «одноголосно» ухвалювали загальні збори колективів.

Карали студентську молодь і за те, що, знаючи про роботу «ворогів народу», своєчасно не доповіли про це в органи держбезпеки. го жовтня 1934 р. сувору догану оголосили студентові Одеського німецького педінституту А.Нікелю, котрий не доніс на свого товариша I.Ланца ${ }^{248}$.

Механізм репресій мав спланований характер. Спущені згори інструкції про створення та наступний розгром «контрреволюційних організацій» були чіткими, а самі ці «об'єднання», за задумом слідчих та їхніх керівників, мали свою ієрархію. У квітні 1934 р. відбувся «процес Польської організації військової», метою якої було нібито «відірвання» від СРСР України, Білорусії та долучення їх до федерації з Польщею249. У розд. 6 обвинувального висновку стверджувалося, що основною «бойовою та організаційною базою» став Польський педінститут, який «за завданням московського керівництва ПОВ повинен був зайнятися підготовкою організаторських, пропаґандистських і військових кадрів для повстання». У документі констатувалася «шкідницька робота» у закладі щодо комплектування його студентством: «Керований ставлениками ПОВ, особливо Сохацьким, інститут перетворився на розсадник польського націоналізму на Україні, що підготовляв націоналістичні кадри учителів для польських шкіл» ${ }^{250}$.

Точних даних стосовно персонального складу учасників цієї фіктивної «контрреволюційної організації» немає, однак можемо констатувати, що серед них було багато студентів, зважаючи на те, що впродовж 2-го семестру 1933/1934 навч. р. число вихованців вишу зменшилося з 278 до I60 251. У 1933 р. заарештували Мулька, Повніковську, Тожкову, які, на думку «чекістів», були «активними контрреволюціонерами» ${ }^{252}$. У 1935 р. із навчального закладу відрахували Валевського, Венцевича, Лісовського, Чухлевську, котрі нібито «мали зв’язки» з ПОВ та іншими «контрреволюційними організаціями». Шліферштейна звинуватили в тому, що він був польським «легіонером» ${ }^{253}$.

Співробітники держбезпеки «виявили», що на початку 1932 р. «осередок ПОВ» було створено у Проскурівському польському педтехнікумі, який очолили директор закладу І.Струтинський і завідувач навчальної частини П.Дума. До його складу ввійшли II осіб, у тому числі студенти Й.Зайонц, Й.Кшивановський, М.Шостак²54. Вони вступили до організації в 1933 р. і нібито проводили «обробку» слухачів із метою «вербовки» їх

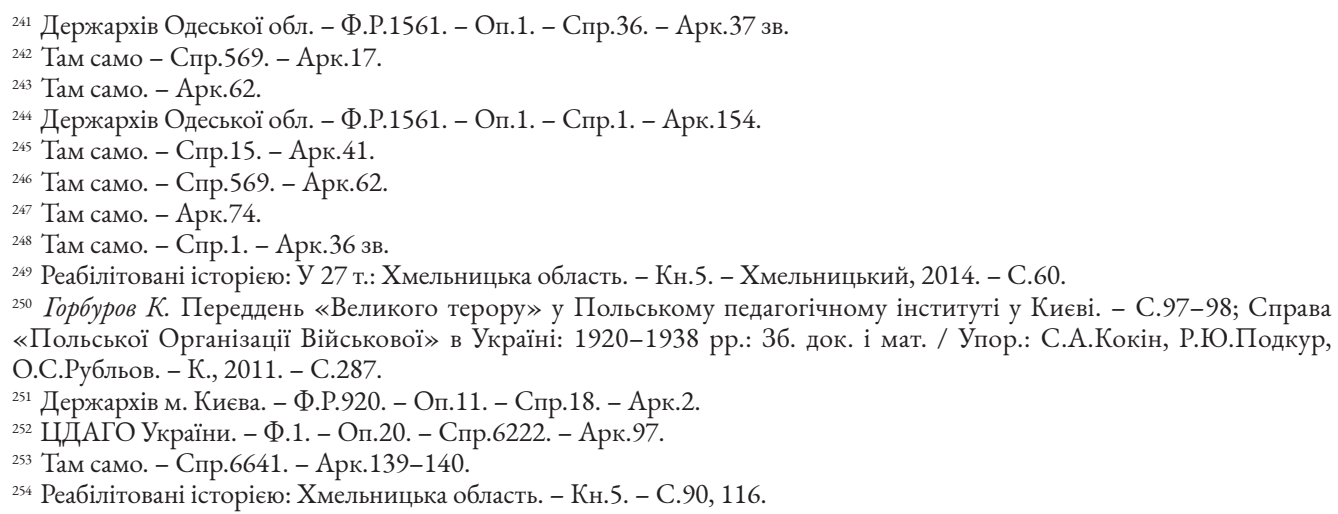


у ПОВ 255 У справі проходили також вихованці Польського педінституту П.Шклярук 256 , Київського польського педагогічного технікуму Ясницький і Добржанський ${ }^{257} .23$ лютого 1934 р. в обвинувальному висновку зазначалося, що М.Шостака засудили на 5 років позбавлення волі в таборі, Й.Зайонця та Й.Кшивановського мали вислати за межі республіки на 5, а П.Шклярука - на 3 роки ${ }^{25}$.

Студентів активно залучали до обговорення сфабрикованих гучних політичних справ, де вони засуджували «ганебні виступи» проти радянської влади. Так, у червні 1934 р. учасники загальних зборів студентів, аспірантів, викладачів і співробітників Польського педінституту подякували ЦК КП(б)У за «розгром контрреволюційного націоналізму і його агентури» на чолі зі М.Скрипником, а також за поразку «контрреволюційної школи польського фашизму» у виші 259 .

Таким чином, у г920-1930-х рр. для радянізації молоді, нав’язування їй більшовицької ідеології використовували різні засоби. Партійні та комсомольські осередки закладів педагогічної освіти національних меншин практикували організацію політгуртків, політичних і комсомольських шкіл, «політбоїв», «соціалістичного змагання», пропагування атеїстичних ідей, відзначення державних і революційних свят, ушанування пам'яті вождів тощо. Усе ж ці заходи, а, власне, і самі осередки, авторитетом серед студентів здебільшого не користувалися. Натомість у молодіжному середовищі популярними були різноманітні диспути та дискусії на політичні теми з вільним обміном думками, що, на думку влади, несло загрозу «марксистському світогляду». Громадську діяльність студентів було підпорядковано ідеологічним настановам партії. Зокрема їх залучали до роботи у складі профспілок, громадських організацій, гуртків, до участі у загальнодержавних кампаніях, шефській роботі у селах, на підприємствах міст, у робітничих клубах, підрозділах Червоної армії, до ліквідації неписьменності тощо. Загалом студенти педагогічних освітніх закладів нацменшин були менш активними у громадській роботі, особливо на селі, ніж їхні колеги з українських вишів. Частина вихованців не сприйняли більшовицьку модель суспільства, наслідком чого стали репресії у студентському середовищі.

\section{REFERENCES}

1. Altukhova, O.I. (1999). Pro polskyi pedahohichnyi tekhnikum v m. Proskurovi. Poliaky na Khmelnychchyni: pobliad kriz viky, 347-350. Khmelnytskyi. [in Ukrainian].

2. Babko, Yu. (1971). Partiine budivnytstvo na Ukraini u 1933-1937 rr. Lviv. [in Ukrainian].

3. Chyrko, B. (1995). Natsionalni menshyny v Ukraini (20-30 rr. XX st.). Kyiv. [in Ukrainian].

4. Dvirna, K. (2011). Stvorennia i likvidatsiia Polskoho pedahohichnoho instytutu v m. Kyievi v 30-kh rr. XX st. (arkhivna rozvidka). Volynski istorychni zapysky, 6, 149-155. Zhytomyr. [in Ukrainian].

5. Horburov, K. (2013). Peredden „Velykoho teroru” u Polskomu pedahohichnomu instytuti u Kyievi. Politychni represii v Ukrainskii RSR 1937-1938 rr.: doslidnytski refleksii ta interpretatsii: Do 75-richchia „Velykoho teroru” v SRSR, 90-106. Kyiv. [in Ukrainian].

6. Klitsakov, I. (1997). Pedabohichni kadry Ukrainy (1917-1937 rr.). Donetsk. [in Ukrainian].

7. Komarnitskyi, O. (2017). Studenty-pedabohy u modernizatsii vyshchoi osvity radianskoi Ukrainy u 1920-1930-kb rr. KamianetsPodilskyi. [in Ukrainian].

8. Kulchytskyi, S. (Ed.). (2012). Ukrainske radianske suspilstvo 30-kb rr. XX st.: narysy pousiakdennobo zhyttia. Kyiv. [in Ukrainian].

9. Lavrut, O. (2009). Studentska presa v USRR periodu 20-kh rr. XX st. Gileia, 28, 45-56. Kyiv. [in Ukrainian].

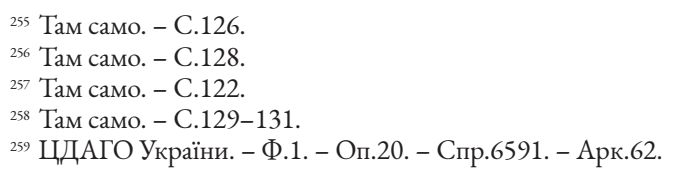


10. Morozan, O. (2019). Derzhavna polityka shchodo studentskoi molodi u 20-30-ti rr. XX st.: sutnist ta osnovni tendentsii. Naukovyi visnyk Mykolaivskoho derzhavnoho universytetu im. V.O.Sukbomlynskobo: Ist. nauky, 1(47), 5-10. Mykolaiv. [in Ukrainian].

11. Paniotov, I. (1973). Komunistychna partiia Ukrainy v borotbi za rozvytok narodnoi osvity (1931-1941 rr.). Kharkiv. [in Ukrainian].

12. Riabchenko, O. (2012). Studenty radianskoi Ukrainy 1920-1930-kh rr.: praktyky povsiakdennosti ta konflikty identyfikatsii. Kharkiv. [in Ukrainian].

13. Shevchuk, H. (1963). Kulturne budivnytstvo na Ukraini u 1921-1925 rr. Kyiv. [in Ukrainian].

14. Yefimenko, H. (2001). Natsionalno-kulturna polityka VKP(b) shchodo radianskoi Ukrainy (1932-1938). Kyiv. [in Ukrainian].

\title{
Oleksandr KOMARNITSKYI
}

Doctor of Historical Sciences (Dr. Hab. in History), Docent,

Professor at Department of History of Ukraine,

Kamianets-Podilskyi I.Ohiienko National University

(Kamianets-Podilskyi, Ukraine), kob-1974@ukr.net

ORCID: https://orcid.org/oooo-0oo3-302I-6550

\section{Iryna NEDOSHYTKO}

Candidate of Historical Sciences (Ph. D. in History),

Docent at Department of Information and Socio-Cultural Activity,

West Ukrainian National University

(Ternopil, Ukraine), i.nedoshytko@ukr.net

ORCID: https://orcid.org/oooo-oooI-9233-7169

\section{Bolshevization of Students of Pedagogical Education Institutions of National Minorities in Ukrainian SSR in the 1920s - 1930s: Purpose, Means, Tasks}

\begin{abstract}
The purpose of the study is to clarify the purpose, means and objectives of Bolshevization students of pedagogical educational institutions of national minorities in the 1920s and 1930s, coverage of socio-political and educational activities of student youth, purposeful and controlled by party and Komsomol cells in pedagogical colleges and institutes, in general, party-state structures, as well as manifestations of opposition among her. Research methods. The authors used a set of general scientific (analysis, synthesis, method of comparison, dialectical) and special scientific (historicalgenetic, historical-comparative, historical-typological, problem-chronological) methods of historical cognition. Scientific novelty. The social and political life of the students of pedagogical educational institutions through the prism of its Bolshevization, subordination to the means and tasks of the Soviet-Stalinist leadership in the interwar period is analyzed. Conclusions. For the Bolshevization of student youth, the imposition of Soviet-Stalinist ideology and the model of society, party and Komsomol cells in the educational institutions of national minorities practiced the organization of political circles, circles of "current politics", political and Komsomol schools, "political battles", "socialist competition", propaganda of atheistic ideas, celebration of state holidays, honoring the memory of Bolshevik leaders, etc. In practice, such events, and in fact the party and Komsomol committees themselves, did not enjoy the proper authority among students. Instead, various debates and discussions on political topics with a free exchange of views were popular among young people, which, according to the authorities, posed a threat to the development of a "Marxist worldview". The socio-political and educational activities of students were subordinated to the political and ideological guidelines of the Bolshevik Party and the Komsomol. In particular, they were involved in work in trade unions, public organizations, clubs, in various national campaigns, boss work in villages, urban enterprises, workers' clubs, units of the Red Army, the elimination of illiteracy and more. In general, students of pedagogical colleges and institutes were less active in social work, especially in rural areas, than their colleagues from purely Ukrainian universities. Some students did not accept the Bolshevik model of society, which strengthened their opposition, which inevitably led to repression in their environment.
\end{abstract}

Keywords: students, pedagogical institute, technical school, Bolshevik ideology, committee, social competition. 